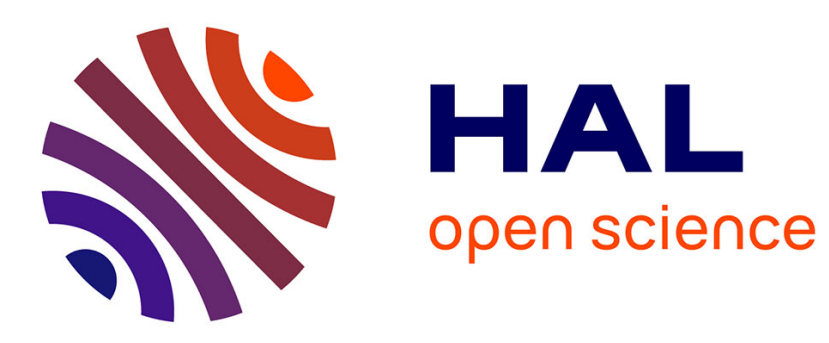

\title{
Impact of climate warming on plant growth varied according to the season
}

Márcio José Silveira, Gabrielle Thiébaut

\section{To cite this version:}

Márcio José Silveira, Gabrielle Thiébaut. Impact of climate warming on plant growth varied according to the season. Limnologica, 2017, 65, pp.4-9. 10.1016/j.limno.2017.05.003 . hal-01580359

HAL Id: hal-01580359

https://hal-univ-rennes1.archives-ouvertes.fr/hal-01580359

Submitted on 1 Sep 2017

HAL is a multi-disciplinary open access archive for the deposit and dissemination of scientific research documents, whether they are published or not. The documents may come from teaching and research institutions in France or abroad, or from public or private research centers.
L'archive ouverte pluridisciplinaire HAL, est destinée au dépôt et à la diffusion de documents scientifiques de niveau recherche, publiés ou non, émanant des établissements d'enseignement et de recherche français ou étrangers, des laboratoires publics ou privés. 


\section{Impact of climate warming on plant growth varied according to the season}

${ }^{a, b}$ Márcio José Silveira and ${ }^{\mathrm{b} *}$ Gabrielle Thiébaut

a State University of Maringá - UEM Research group in Limnology, Ictiology and Aquaculture - Nupelia Laboratory of Limnology and Aquatic Macrophytes

bUniversity of Rennes 1, UMR CNRS Ecosystemes, Biodiversite', Evolution, 35042

Rennes, France

*Corresponding author: gabrielle.thiebaut@univ-rennes1.fr

Highlights

-Climate warming stimulates the growth of invasive aquatic plants in spring.

-a rise of temperature had a greater impact on plant traits in spring than in summer and in winter

- The growth of E. canadensis will be higher than those of E. densa and L. major independently of the season 


\begin{abstract}
Climate changes will promote the growth of invasive aquatic macrophytes. The aim of our study was to analyse the responses of three invasive plants (Elodea canadensis, Egeria densa and Lagarosiphon major) to a temperature increase of $3{ }^{\circ} \mathrm{C}$ in spring, summer and winter. At each season we measured four functional traits: the Relative Growth Rate 'RGR', Relative Leaf surface area Growth Rate, number of lateral branches and roots. E. canadensis showed the highest growth and vigour in spring and in summer. The Relative Growth Rate was enhanced by an elevation of temperature for E. canadensis and for E. densa. A $3^{\circ} \mathrm{C}$ temperature increase stimulated root production for all species in summer, whereas the number of lateral branches was favoured in spring for E. canadensis. Climate warming had a greater impact on plant growth in spring than in summer and late winter. The response of species to climate warming was species-specific and so an increase in temperature should favour the spread of $E$. canadensis.
\end{abstract}

Keywords: Elodea canadensis; Lagarosiphon major; Egeria densa; temperature increase; functional traits 


\section{Introduction}

In its $5^{\text {th }}$ report, the IPCC estimates that global temperatures will have increased by $1.2^{\circ} \mathrm{C}$ to $4^{\circ} \mathrm{C}$ by 2100 (IPCC, 2013). Rises in temperature, $\mathrm{CO}_{2}$ concentrations and precipitation changes directly and indirectly affect the phenology, productivity and distribution of aquatic vegetation (Wrona et al., 2006; Heikkinen et al., 2009; Heino et al., 2009; Peeters et al., 2013). Moreover, changes in climate alter the physical, chemical and biological characteristics of freshwater ecosystems (Wrona et al., 2006; Rahel and Olden, 2008; Ejankowski and Lenard, 2015; Dhir, 2015). Besides the ecological functions assigned to macrophytes (as primary producers, sources of habitats and refuges), it becomes essential to study and discuss the effects of climate changes. Changes of climatic characteristics and hydrology are predicted to induce seasonal fluctuations of macrophyte biomasses. When both air and water temperatures rise and the day-length becomes longer in spring, macrophyte production increases. Conversely, lower temperatures and the shorter day-length in the autumn cause a decrease in macrophyte production and growth (Madsen and Adams, 1988; Riis et al., 2003). Field studies indicate that warming results in an earlier start to the growing season; it stimulates growth and increases the spatial extent of macrophyte communities in clearwater lakes (Rooney and Kalff, 2000). Climate warming may enhance the potential success of invasive species (Rahel and Olden, 1988; Patrick et al., 2012). Higher winter temperatures may increase exotic plant survival in thermal streams (Hussner and Lösch, 2005; Sajna et al., 2007). Certain invasive species colonize faster at higher temperatures in outdoor experiments with mesocosms (McKee et al., 2002; Hussner, 2009; Riis et al., 2012). Moreover, as invasive species have already invaded climate envelopes quite different from their area of origin, the introduced populations may have the ability to adjust to changing climate. The aquatic plant species that have the highest temperature 
threshold value will be favoured and these mainly include invasive submerged macrophytes such as Hydrilla verticillata and Myriophyllum spicatum (Hughes, 2000; Rooney and Kalff, 2000).

Among the world's worst invasive freshwater plants, three species: Elodea canadensis Michaux, Egeria densa Planchon and Lagarosiphon major (Rid.) Moss ex Wager (belonging to the Hydrocharitaceae family), are widespread in European ponds, streams and reservoirs (Cook and Urmi-König, 1984, 1985; McKee et al., 2002). These species are able to form dense pure stands. Native to North America, only female plants of Elodea canadensis were introduced outside its native range (Cook and Urmi-König, 1985). E. canadensis, first recorded in the early 19th century in the British Isles is now naturalised (Thiébaut, 2007). E. canadensis is considered to be stenothermic with optimum temperatures ranging between 10 and $25^{\circ} \mathrm{C}$ (Madsen and Brix, 1997). Native from South America, E. densa appears to be confined to warm-temperate and cool subtropical conditions (Cook and Urmi-König, 1984). Only male plants of E. densa were introduced in France and they have been in cultivation since at least 1919. L. major is native to high altitude temperate regions of southern Africa (James et al., 1999; McKee et al., 2002), and is therefore not adapted to high tropical temperatures. L. major was introduced to Paris (France) in the 1930's, although only the female plant is known outside its native range. Its optimum growth is between 20-23 degrees Celsius and can be absent below temperatures of $10^{\circ} \mathrm{C}$ (Natural Heritage Trust, 2003).

The aim of our study was to assess experimentally in the laboratory, how an increase in water temperature may influence the seasonal morphological responses of these three non-native aquatic plants. The impact of warmer temperatures depends mainly on the development stage of the plant when the warming occurs (Hasanuzzaman et al., 2013) and on plant thermal tolerance. While E. canadensis has a wider thermal 
tolerance than the other two species, it has the ability to growth under a wide range of temperature. It can adjust more quickly its responses to climate changes than the two other species coming from a different climate. L. major and E. densa colonize only the western part of France and, the introduced populations were adapted to an oceanic climate, whereas E. canadensis is widespread in french freshwaters from sub continental climate until Mediterranean climate. Our hypotheses were that warming has a greater impact on plant growth when seasonal temperatures are usually mild (in spring) than when the climatic conditions are already hot (in summer), and that the growth of the invasive species E. canadensis will be enhanced by increasing temperature, independently of the season.

\section{Methods}

The species used in the experiment were collected from 3 different eutrophic ponds located in Brittany in western France (Table 1): at the end of winter (March), in spring (May) and in summer (July). Moreover, E. densa and E. canadensis were found in alkaline waters, whereas L. major was sampled in acidic to slightly acidic waters (Table 1).

\subsection{Experimental design}

Firstly, for each sampling session in the different seasons (winter, spring and summer) apical shoots of E. canadensis, E. densa and L. major without roots, buds or lateral shoots were collected and washed to remove invertebrates, algae and debris. Then containers (dimensions $(\mathrm{L} \times \mathrm{W} \times \mathrm{H}): 8 \mathrm{~cm} \times 8 \mathrm{~cm} \times 15 \mathrm{~cm}$ ) were prepared with sediment ( $2 \mathrm{~cm}$ of substrate (loam) and $3 \mathrm{~cm}$ of sand). Submerged plants take up most of nutrients from the sediment (Thomaz et al., 2007) thus, fertile finely grained sediments, such as loam, contain high organic matter contents with anaerobic conditions 
and nutrients which are suitable for L. major growth (Martin and Coetzee, 2014) and for other macrophyte species.

In each container, four apical shoots, $7 \mathrm{~cm}$ in length, without roots, buds or lateral branches, were planted. There were five replicates per species and all containers were filled with tap water which was slightly basic with a moderate nutrient concentration (mean annual value according to French Water Agency data: conductivity $=400 \mu \mathrm{S} \mathrm{cm}^{-1} ; \mathrm{pH}=8.10 ;\left[\mathrm{NO}_{3}{ }^{-} \mathrm{N}\right]=1.44 \mathrm{mg} \mathrm{L}^{-1} ;\left[\mathrm{NH}_{4}{ }^{+} \mathrm{N}\right]=0.03 \mathrm{mg} \mathrm{L}^{-1} ;\left[\mathrm{PO}_{4}{ }^{3-} \mathrm{P}\right]=$ $\left.0.05 \mathrm{mg} \mathrm{L}^{-1}\right)$. The containers were randomly distributed in grow chambers for a period of four weeks. The growth chambers were programmed with the chosen temperatures: Treatment 1 simulated the minimal temperature found during winter in Brittany: 3 and $6^{\circ} \mathrm{C}$ (because the field sampling was carried out at the end of winter with an average water temperature of $13.5^{\circ} \mathrm{C}$, before the starting the experiment the plants used in this treatment were submitted to a process of acclimatization (one week), during which the temperature was decreased gradually. This procedure was necessary so that the low temperatures used in this treatment did not cause thermal shock in the plants). Treatment 2 simulated spring temperatures: 16 and $19^{\circ} \mathrm{C}$. Treatment 3 simulated the summer temperatures: 20 and $23^{\circ} \mathrm{C}$. The plants sampled in spring and summer were maintained in tanks at ambient temperature during one week. The temperatures of 3,16 and $20^{\circ} \mathrm{C}$ correspond respectively to the mean winter, spring and summer temperatures in Brittany region. Water temperatures were increased by $3^{\circ} \mathrm{C}$ above the mean seasonal water temperatures in Brittany (an average increase of about $3{ }^{\circ} \mathrm{C}$ in the IPCC A2 model scenarios).Within the chambers, light intensity was about $300 \mu \mathrm{mol} \mathrm{m} \mathrm{m}^{-2} \mathrm{~s}^{-1}$ with a photoperiod $12 \mathrm{~h}$ of light/12 $\mathrm{h}$ of darkness. This light intensity was chosen because these three non-native species may have a growth optimum under these light conditions (Riis et al., 2012). 


\subsection{Morphological responses}

At the beginning and at the end of the experiment, the length of each shoot and the leaf surface area were measured. To calculate the leaf surface area, a leaf was removed manually from the shoot. After that, the leaf of each apex was scanned using a flatbed scanner at a resolution of 800 dpi (Epson Perfection 1200PHOTO). Its projected area was then determined (PHOTOSHOP ver. 8, Adobe Systems Inc., San Jose, CA). We added four new functional traits at the end of the experiment: relative growth rates (RGR), relative leaf surface area growth rate (RLGR), number of lateral branches and roots produced. The relative growth rates (RGR) of the macrophytes were calculated according to the following equation: $\mathrm{RGR}=(\ln L 2-\ln L 1) /(T 2-T 1)$, where $L 1$ and $L 2$ refer to plant length at times 1 and 2 (Barrat-Segretain and Elger, 2004). The RLGR were calculated according to the same equation than the RGR. The difference was that $\mathrm{L} 1$ and L2 refer to the leaf are surface.

\subsection{Statistical analyses}

Statistical analyses were carried out with Statistica TM 7.0.a software. A twoway ANOVA was performed to test for each species (E. canadensis, E. densa and $L$. major) the effects of season (winter, spring, summer) and temperature (reference temperature $\mathrm{T} 0$ and the treatment $\mathrm{T}=\mathrm{T} 0+3^{\circ} \mathrm{C}$ ), and their interactions. Normality and homogeneity were tested using Bartlett's test and showed that no transformation was necessary. A Tukey post hoc test was performed.

\section{Results}

The results demonstrated that for the Relative Growth Rate of L. major, leaf area growth of $E$. densa and the number of roots of each species, there were significant interactions between temperature and season (Table 2). Whatever the season, $E$. 
canadensis had a significantly higher growth rate than the other species used in the experiment (Fig.1a).

A temperature increase of $3^{\circ} \mathrm{C}$ significantly favoured the growth of all species in spring, of E. canadensis and E. densa in summer and only of E. densa in winter (Fig. $1 \mathrm{a}, \mathrm{b}, \mathrm{c})$. The temperature increase significantly favoured the leaf area growth of $E$. densa in spring, although the leaf area growth decreased strongly from late winter to spring and summer for all the species (Fig. 1d, e, f). Despite, the temperature increase, there was no effect on the production of lateral branches in summer season for any of the species (Table 2; Fig. 1j, 1). Moreover, E. densa did not produce lateral branches during any of the seasons (winter, spring or summer) whatever the temperature to which the species was submitted (Fig. 1). However, the production of lateral branches of $E$. canadensis in spring (Fig. 1j) and the root production for all species in summer were stimulated by the temperature elevation (Fig. 1g, h, i).

\section{Discussion}

\subsection{Effects of increased temperature on plant growth varied according to the season}

Our results showed that an elevation of the temperature favoured the relative growth rate in spring for each species and in winter only for $E$. densa. We also established that summer warming increased the growth of E. canadensis and E. densa. These findings are in accordance with the expected outcomes and the literature for $E$. densa and E. canadensis. For example, Barko et al. (1982) established that shoot length of E. canadensis increased with increasing temperature $\left(12\right.$ to $\left.32^{\circ} \mathrm{C}\right)$, and Riis et al., (2012) between 20 and $25^{\circ} \mathrm{C}$. The optimum growth temperature of $E$. densa reported by Cook and Urmi-König (1984) is $16^{\circ} \mathrm{C}$ and the maximum temperature for growth is $25^{\circ} \mathrm{C}$. However, we did not find a higher growth rate in summer or with a summer 
temperature increase for L. major, even though its optimum growth is between $20-23^{\circ} \mathrm{C}$, with a maximum temperature of approximately $25^{\circ} \mathrm{C}$ (McKee et al., 2002).

We also showed that a temperature increase stimulated the root production in summer for all tested species. Plants may need more nutrients to resist to temperature rise. The production of roots at the highest temperatures may therefore indicate a plant capacity to optimize the uptake of resources (Cao et al., 2015). The spring warming stimulated the production of lateral branches for E. canadensis. Active growth of Elodea canadensis (above $15^{\circ} \mathrm{C}$ ) quickly produced a thick-branched mat during the summer (Sheppard et al., 2006). On the other hand, the same was not observed for $E$. densa in spring and summer and L. major in spring. These results are surprising, as Haramoto and Ikusima (1988) showed that lateral branches of E. densa with roots were developed and elongated towards the water surface when the water temperature became higher than $15^{\circ} \mathrm{C}$, and that optimum growth rate occurred at a temperature of $20.7^{\circ} \mathrm{C}$. However in a previous study, we established that the regeneration abilities of different naturalized populations of $E$. densa submitted to increasing warming varied according to the origin of the population (Thiébaut et al., 2016). Surprisingly, leaf growth was strongly reduced in spring and summer during the vegetative growing season. This result suggests that the plants allocated their energy to apical growth, and not to the leaves. However, a temperature increase stimulated the leaf growth of $E$. densa in spring.

Aquatic macrophytes are able to grow and multiply vegetatively at cool, and even cold temperatures (Boylen and Sheldon, 1976; Olesen and Madsen, 2000), although Pilon and Santamaria (2001) established that aquatic species have a limited capacity for thermal acclimatization. We established that the growth of E. canadensis and L. major were not stimulated by the temperature elevation in winter, and despite of 
these species had showed a low growth in this season, they may have partly entered into a dormant stage due to the low temperature. A temperature of $7^{\circ} \mathrm{C}$ was probably close to the lower limit for positive growth of Elodea (Madsen and Brix, 1997). Later, using data for E. canadensis, Olesen and Madsen (2000) found a negative relationship between degree of temperature stress and photosynthetic performance. In the Northern hemisphere, L. major becomes dormant in the winter and emerges in the spring from rhizomes and shoots and it is thought to be absent below temperatures of $10^{\circ} \mathrm{C}$ (Natural Heritage Trust, 2003), this could explain the low growth of this species in winter at the lowest temperature. For $E$. densa the growth rate increased slightly with the rise of temperature in late winter, suggesting a rather slow response to temperature during this season. It is well adapted to cold climates and can survive freezing conditions during the winter by storing starch in its leaves and stems, and by using these supplies for growth once temperatures rise above $10^{\circ} \mathrm{C}$ (Haramoto and Ikusima, 1988). The growth of $E$. densa under winter warming might be explained by a lack of dormancy throughout the winter season. The underground organs and particularly their reserve substances are important for the survival of perennials through adverse periods, including winter.

Thus, an elevation of the spring temperature had an impact on plant performance (stimulation of the relative growth rate of all species, increase of leaf area of $E$. densa and higher production of branches of E. canadensis), whereas a summer rise favoured the root production of all species and the RGR of E. canadensis and E. densa. Thus, our first hypothesis was not validated for all the species.

\subsection{Will E. canadensis demonstrate better performance under climate warming?}

Our results demonstrated that E. canadensis was the species that showed the highest development of all traits in spring and summer. On the other hand, E. densa and L. major showed low growth of all their traits. These differences suggest species- 
specific responses to temperature rise among invasive species, potentially favouring the growth of plants with a wide thermal range such as E. canadensis. Thus, our initial hypothesis that the invasive species $E$. canadensis will perform better than the other two species with increasing temperature was validated.

The higher growth rate of E. canadensis demonstrated in spring and summer, means that it could have an ecological advantage over $E$. densa and L. major. E. canadensis is able to occupy the available space in aquatic environments very quickly, thereby pre-empting the acquisition of resources and space, which could help it to inhibit the development of other species. Thus, E. canadensis may be a species with greater competitive potential relative to other species, at different seasonal period (e.g. spring and summer) exception for winter, with the ability to colonize different aquatic environments faster compared to E. densa or L. major. The ability of E. canadensis to modify its traits over a range of temperatures suggests a high phenotypic plasticity. Conversely, the low growth rate of $L$. major suggests less phenotypic plasticity. This implies that E. canadensis is more a generalist than the other species, and L. major the least invasive (Riis et al., 2012). Climate warming also promotes the establishment of $E$. canadensis in higher latitude systems, as temperatures become more similar to the optimal range of the species (Heikkinen et al., 2009; Zehnsdorf et al., 2015). Patrick et al. (2012) showed that warmer water as a result of climate change will extend the growing season for the invasive species, but not for the native plants. Future studies focused on evaluating the morphological responses of native species to rising temperature are required.

Our results are difficult to extrapolate to the field and to continuous warming. To test our hypothesis, a study could be expanded to assess whether the results of our microcosm studies can be validated in the natural ecosystems in which the focal species 
are found. Moreover, the climate warming increases the availability of phosphorus to plants. High phosphorus concentrations increase competition between macrophytes and phytoplankton (Lacoul and Freedman, 2006). Warming lead to a shift from a clear, macrophyte dominated state to a turbid, phytoplankton-dominated state (Mooij et al., 2007). Long-term experiments on the impact on climate warming on the biotic interactions are needed to fully understand the dynamic responses of ecosystem to climate change.

\section{Acknowledgements}

We thank Bertrand Coupé and Marc Hervé for their help in the field and Nathalie Josselin-Le Bris for assistance with water analyses.

\section{References}

1. Barko, J.W., Harding. D.G., Matthews, M.S., 1982. Growth and morphology of submersed macrophytes in relation to light and temperature. Can. J. Bot. $60,877-887$.

2. Barrat-Segretain, M-H., Elger, A., 2004. Experiments on growth interactions between two invasive macrophytes species. J. Veg. Sci. 15, 109-114.

3. Boylen, C.W., Sheldon, R.B., 1976. Submerged macrophytes: growth under winter ice cover. Science. 194, 841-842

4. Cao. Y., Neif, É.M., Li, W., Coppens, J., Filiz, N., Lauridsen, T.L., Davidson, T.A., Sondergaard, M., Jeppesen, E., 2015. Heat wave effects on biomass and vegetative growth of macrophytes after long-term adaptation to different temperatures: a mesocosm study. Clim. Res. 66, 265-274.

5. Cook, C.D.K., Urmi-König, K., 1985. A revision of the genus Elodea (Hydrocharitaceae). Aquat. Bot. 21, 111-156. 
6. Cook, C.D.K., Urmi-König, K., 1984. A revision of the genus Egeria (Hydrocharitaceae). Aquat. Bot. 19, 73-96.

7. Dhir, B., 2015. Status of Aquatic Macrophytes in Changing Climate: A Perspective. J. Environ. Sci. Technol. 8, 139-148.

8. Ejankowski, W., Lenard, T., 2015. Climate driven changes in the submerged macrophyte and phytoplankton community in a hard water lake. Limnologica. 52, 59-66.

9. Haramoto, T., Ikusima, I., 1988. Life cycle of Egeria densa Planch., an aquatic plant naturalized in Japan. Aquat. Bot. 30, 389-403.

10. Hasanuzzaman, M., Nahar, K., Alam, M.M., Roychowdhury, R., Fujita, M., 2013. Physiological, biochemical, and molecular mechanisms of heat stress tolerance in plants. Int. J. Mol. Sci. 14, 9643-9684.

11. Heikkinen, R., Leikola, N., Fronzek, S., Lampinen, R., Toivonen, H. 2009. Predicting distribution patterns and recent northward range shift of an invasive aquatic plant: Elodea canadensis in Europe. BioRisk. 2, 1-32.

12. Heino. J., Virkkala, R., Toivonen, H., 2009. Climate change and freshwater biodiversity: Detected patterns, future trends and adaptations in northern regions. Biol. Rev. 84, 39-54.

13. Hughes, L., 2000. Biological consequences of global warming: Is the signal already apparent. Trends Ecol. Evol. 15, 56-61.

14. Hussner. A., Lösch, R., 2005. Alien aquatic plants in a thermally abnormal river and their assembly to neophyte-dominated macrophyte stands (River Erft, Northrhine-Westphalia). Limnologica. 35, 18-30.

15. Hussner, A., 2009. Growth and photosynthesis of four invasive aquatic plant species in Europe. Weed. Res. 49, 506-515. 
16. IPCC., 2013. Long-term Climate Change: Projections, Commitments and Irreversibility, in: Climate Change 2013 - The Physical Science Basis. Cambridge University Press, Cambridge, pp. 1029-1136.

17. James, C.S., Eaton, J.W., Hardwick, K., 1999. Competition between three submerged macrophytes, Elodea canadensis Michx, Elodea nuttallii (Planch.) St John and Lagarosiphon major (Ridl.) Moss. Hydrobiologia. $415,35-40$.

18. Lacoul, P., Freedman, B., 2006. Environmental influences on aquatic plants in freshwater ecosystems. Environ. Rev. 14, 89-136.

19. Madsen, J.D., Adams, M.S., 1988. The seasonal biomass and productivity of the submerged macrophytes in a polluted Wisconsin stream, Fresh. Biol. 20, 41-50.

20. Madsen, T.V., Brix, H., 1997. Growth, photosynthesis and acclimation by two sub-merged macrophytes in relation to temperature. Oecologia. 110, $320-327$.

21. Martin, G.D., Coetzee, J.A., 2014. Competition between two aquatic macrophytes, Lagarosiphon major (Ridley) Moss (Hydrocharitaceae) and Myriophyllum spicatum Linnaeus (Haloragaceae) as influenced by substrate sediment and nutrients. Aquat. Bot. 114, 1-11.

22. McKee, D., Hatton, K., Eaton, J.W., Atkinson, D., Atherton, A., Harvey, I., Moss, B., 2002. Effects of simulated climate warming on macrophytes in freshwater microcosm communities. Aquat. Bot. 74, 71-83.

23. Mooij, W.M., Janse, J.H., Domis, L.N.S., Hulsmann, S., Ibelings, B.W., 2007. Predicting the effect of climate change on temperate shallow lakes with the ecosystem model PCLake. Hydrobiologia 584, 443-454 
24. Natural Heritage Trust, 2003. Lagarosiphon - Lagarosiphon major. Weed Management Guide. Canberra, Australia: Department of Sustainability, Environment, Water, Population and Communities.

25. Olesen, B., Madsen, T.V., 2000. Growth and physiological acclimation to temperature and inorganic carbon availability by two submerged aquatic macrophyte species, Callitriche cophocarpa and Elodea canadensis. Funct. Ecol. 14, 252-260.

26. Patrick. D.A., Boudrean, N., Bozic, Z., Carpenter, G.S., Langdon, D.M., LeMay, S.R., Martin, S.M., Mourse, R.M., Prince, S.L., Quinn, K.M., 2012. Effects of climate change on late-season growth and survival of native and non-native species of watermilfoil (Myriophyllum spp.): Implications for invasive potential and ecosystem change. Aquat. Bot. 103, $83-88$.

27. Peeters, E.T.H.M., van Zuidam, J.P., van Zuidam, B.G., van Nes, E.H., Kosten, S., Heuts, P.G.M., Roijackers, R.M.M., Netten, J.C.C., Scheffer, M., 2013. Changing weather conditions and floating plants in temperate drainage ditches. J. Applied. Ecol. 50, 585-593.

28. Pilon, J., Santamaria, L., 2001. Seasonal acclimation in the photosynthetic and respiratory temperature responses of three submerged freshwater macrophyte species. New. Phytol. 15, 659-670.

29. Rahel, F.J., Olden, J.D., 2008. Assessing the Effects of Climate Change on Aquatic Invasive Species. Conserv. Biol. 22, 521-533.

30. Riis, T., Biggs, B.J.F., Flanagan, M., 2003. Seasonal changes in macrophyte biomass in South Island lowland streams, New Zealand. J. Mar. Fresh. Res. 37, 381-388. 
31. Riis, T., Olesen, B., Clayton, J.S., Lambertini, C., Brix, H., Sorrell, B.K., 2012. Growth and morphology in relation to temperature and light availability during the establishment of three invasive aquatic plant species. Aquat. Bot. 102, 56-64.

32. Rooney. N., Kalff, J., 2000. Inter-annual variation in submerged macrophyte community biomass and distribution: the influence of temperature and lake morphometry. Aquat. Bot. 68, 321-335.

33. Sajna, N., Haler, M., Skornik, S., Kaligaric, M., 2007. Survival and expansion of Pistia stratiotes L. in a thermal stream in Slovenia. Aquat. Bot. $87,75-79$.

34. Sheppard, A.W., Shaw, R.H., Sforza, R., 2006. Top 20 environmental weeds for classical biological control in Europe: a review of opportunities, regulations and other barriers to adoption. Weed. Res. 46, 93-117.

35. Thiébaut, G., 2007. Non-indigenous aquatic and semi-aquatic plant species in France, in: Gherardi F (ed) Biological invaders in inland waters: profiles, distribution and threats. Springer, Berlin, pp 209-229.

36. Thiébaut, G., Gillard, M., Deleu, C,. 2016. Growth, regeneration and colonisation of Egeria densa fragments : the effect of autumn temperature increases. Aquat. Ecol. 50, 175-185.

37. Thomaz, S.M., Chamber, P.A., Pierini, S.A., Pereira, G., 2007. Effects of phosphorus and nitrogen amendments on the growth of Egeria najas. Aquat. Bot. 86, 191-196.

38. Wrona, F.J., Prowse, T.D., Reist, J.D., Hobbie, J.E., Levesque, L.M.J., Vincent, W.F., 2006. Climate change effects on aquatic biota, ecosystem structure and function. J. Hum. Environ. 35, 359-369. 
39. Zehnsdorf, A., Hussner, A., Eismann, F., Ronicke, H., 2015. Management options of invasive Elodea nuttallii and Elodea canadensis. Limnologica. $51,110-117$. 


\section{Figure Caption}

Figure 1: Mean values and standard errors of the traits at winter, spring and summer: relative growth rate $R G R\left(\mathrm{~cm} \mathrm{~d}^{-1}\right)$; relative leaf area growth $\left(\mathrm{RLGR} \mathrm{cm}^{2} \mathrm{~d}^{-1}\right)$; number of lateral branches; number of roots. The reference temperatures (T0) is illustrated by empty bars and for the treatment $\mathrm{T}\left(\mathrm{T}=\mathrm{T} 0+3^{\circ} \mathrm{C}\right)$ is illustrated by black bars. Different capital letters are used to indicate a significant difference between season, and different small letters are used to indicate a significant difference between temperatures. 
Figure
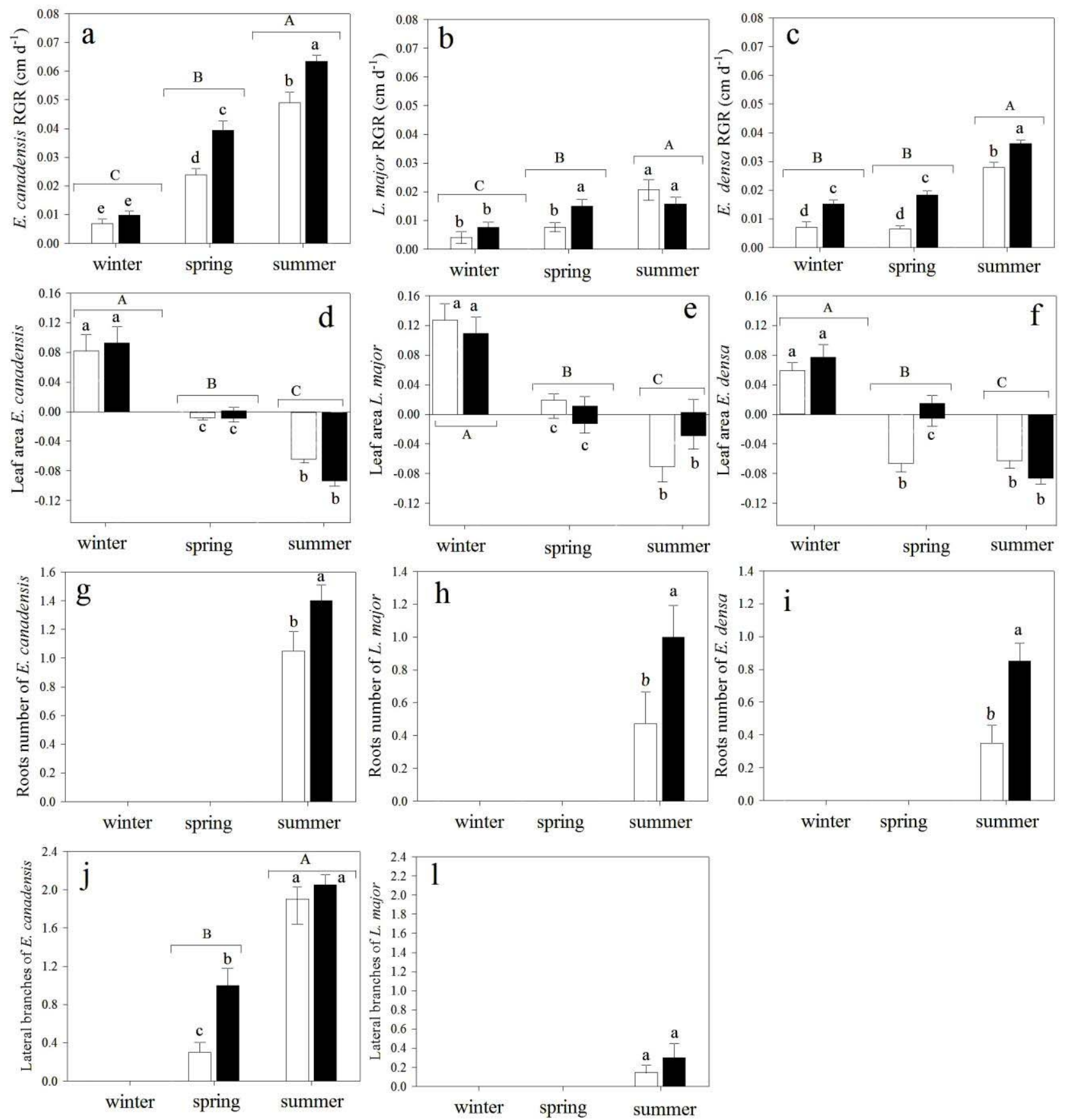

Figure 1 
Table 1: Chemical composition of the water of sampling sites at different season:

winter, spring and summer. Site name, latitudes and longitudes and name of the species sampled in each site are given below.

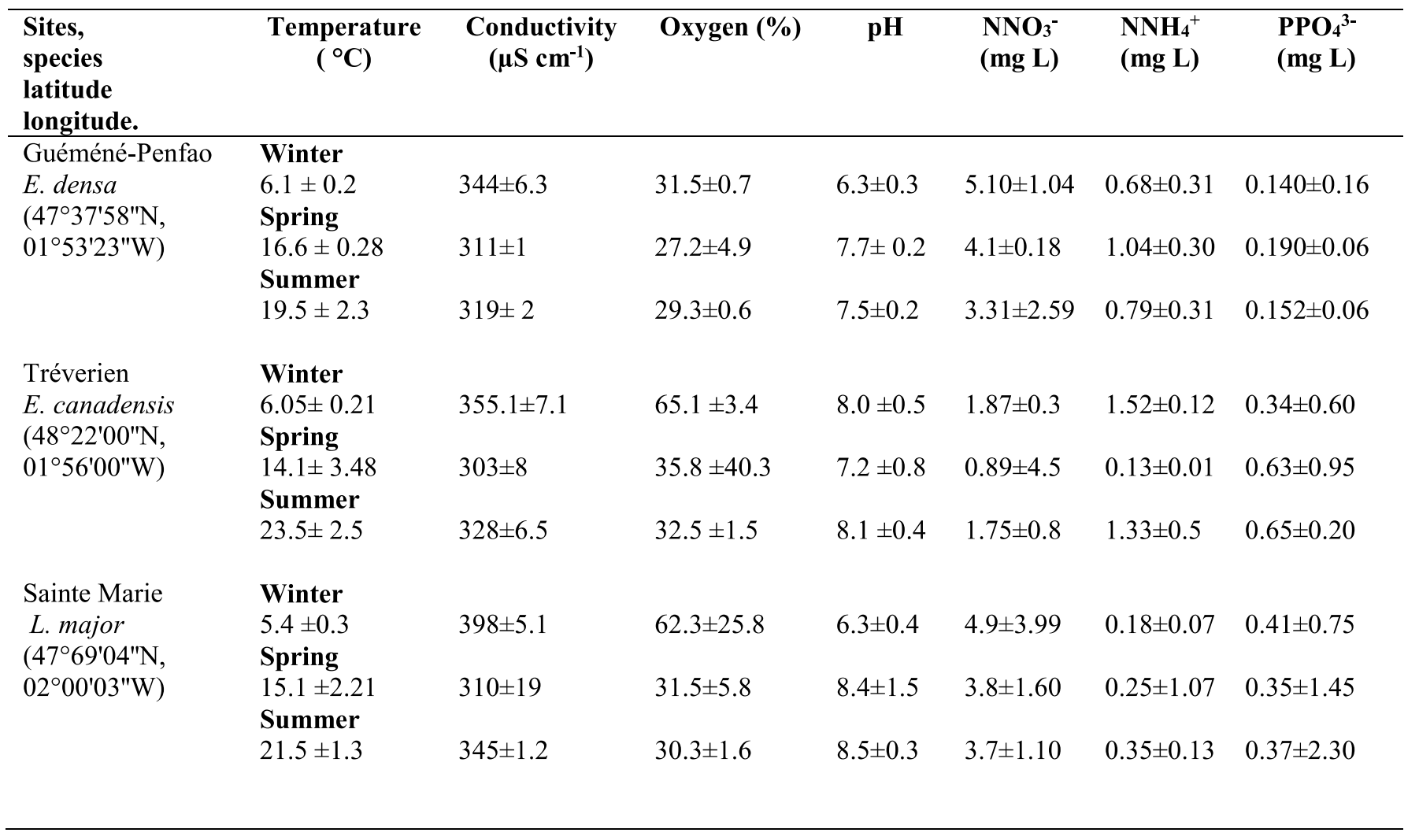


Table 2: Results of two-way ANOVA testing the effects of season and temperature and their interactions, on the morphological traits of E. canadensis, E. densa and L. major.

\begin{tabular}{|c|c|c|c|c|c|c|c|c|c|}
\hline \multirow[b]{2}{*}{ Attributes } & \multicolumn{3}{|c|}{ E. canadensis } & \multicolumn{3}{|c|}{ E. densa } & \multicolumn{3}{|c|}{ L. major } \\
\hline & $d f$ & $F$ & $p$ & $d f$ & $F$ & $p$ & $d f$ & $F$ & $p$ \\
\hline \multicolumn{10}{|l|}{$\operatorname{RGR}\left(\mathrm{cm} \mathrm{d}^{-1}\right)$} \\
\hline Season & 2 & 145.63 & $<0.001$ & 2 & 109.29 & $<0.001$ & 2 & 12.95 & $<0.001$ \\
\hline Temperature & 1 & 23.99 & $<0.001$ & 1 & 53.17 & $<0.001$ & 1 & 1.002 & 0.318 \\
\hline Season X Temperature & 2 & 2.94 & 0.057 & 2 & 0.85 & 0.427 & 2 & 3.46 & 0.034 \\
\hline \multicolumn{10}{|c|}{ Leaf Area RLGR $\left(\mathrm{cm}^{2} \mathrm{~d}^{-1}\right)$} \\
\hline Season & 2 & 121.16 & $<0.001$ & 2 & 68.25 & $<0.001$ & 2 & 35.27 & $<0.001$ \\
\hline Temperature & 1 & 0.008 & 0.927 & 1 & 3.12 & 0.079 & 1 & 0.51 & 0.473 \\
\hline Season X Temperature & 2 & 0.337 & 0.714 & 2 & 8.71 & $<0.001$ & 2 & 3.52 & 0.032 \\
\hline \multicolumn{10}{|l|}{ Lateral branches } \\
\hline Season & 2 & 84.69 & $<0.001$ & - & - & - & 2 & 6.72 & 0.001 \\
\hline Temperature & 1 & 2.85 & 0.093 & - & - & - & 1 & 0.82 & 0.366 \\
\hline Season X Temperature & 2 & 1.33 & 0.267 & - & - & - & 2 & 0.84 & 0.431 \\
\hline \multicolumn{10}{|l|}{ Number of roots } \\
\hline Season & 2 & 173.94 & $<0.001$ & 2 & 59.29 & $<0.001$ & 2 & 28.49 & $<0.001$ \\
\hline Temperature & 1 & 3.39 & 0.068 & 1 & 10.23 & 0.001 & 1 & 3.59 & 0.060 \\
\hline Season X Temperature & 2 & 3.54 & 0.032 & 2 & 10.29 & $<0.001$ & 2 & 3.63 & 0.029 \\
\hline
\end{tabular}

